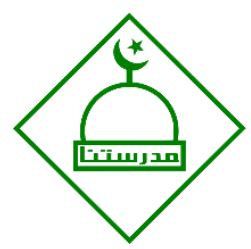

\title{
ANALISIS KEMAMPUAN BERTANYA SISWA PADA MATA PELAJARAN TEMATIK DI SDN 60 KOTA BENGKULU
}

\author{
Irfan Supriatna \\ Universitas Bengkulu ${ }^{1}$, Bengkulu, Indonesia \\ irfansupriatna@unib.ac.id
}

\begin{abstract}
Questioning is a primary part of student learning activities. Questioning activity is asking factual or hypothesis question that begin with guidance from teacher until the student understand themselves and become habitual activity.This research aims to describe Student Questioning Ability in Environment is Our Friend Theme of Environmental Conservation Movement Sub Theme of Thematic Subject and describe the obstacle experienced by the student of $5^{\text {th }}$ Grade 60 Bengkulu City Elementary School year 2019/2020. The method used in this study is qualitative descriptive approach, that is why this research emphasize the processes rather than results. Subjects in this research are 18 students of $5^{\text {th }}$ Grade 60 Bengkulu City using observation and interview sheet instruments. Data collection techniques used were observation, interviews and documentation. The result of this research is there are 7 students who have fulfill all questioning ability indicator requirements, on the other hand there is one student who only achieve one point from the requirements, two requirements of questioning ability indicators fulfill by 6 students, there are two students who can't fulfill any requirement of questioning ability indicators. Obstacles experienced by students have not been able to use Indonesian language correctly, lack focus in asking, lack. of confidence, afraid of being wrong, embarrassed when laughed by their friend and unable to raising the voice so the question can reach the entire class. Conclusion of the research is every student student of $5^{\text {th }}$ Grade 60 Bengkulu City have different questioning ability.

Keywords:Ability, Thematic, Questioning
\end{abstract}

\begin{abstract}
ABSTRAK
Tanya jawab adalah bagian utama dari kegiatan belajar siswa. Kegiatan tanya jawab adalah mengajukan pertanyaan faktual atau hipotesis yang dimulai dengan bimbingan dari guru hingga siswa memahami diri mereka sendiri dan menjadi kegiatan kebiasaan. Penelitian ini bertujuan untuk mendeskripsikan Kemampuan Tanya Jawab Siswa di Lingkungan adalah Tema Teman Kita Gerakan Konservasi Lingkungan Sub Tema Subjek Tematik dan menggambarkan kendala yang dialami siswa kelas V SD Negeri 60 Kota Bengkulu tahun 2019/2020. Metode yang digunakan dalam penelitian ini adalah pendekatan deskriptif kualitatif, oleh karena itu penelitian ini lebih menekankan proses daripada hasil. Subjek dalam penelitian ini adalah 18 siswa kelas V SD Negeri 60 Kota Bengkulu menggunakan instrumen lembar observasi dan wawancara. Teknik pengumpulan data yang digunakan adalah observasi, wawancara dan dokumentasi. Hasil penelitian ini adalah ada 7 siswa yang telah memenuhi semua persyaratan indikator, bertanya, di sisi lain ada satu siswa yang hanya mencapai satu poin dari persyaratan, dua persyaratan dari indikator kemampuan bertanya dipenuhi oleh 6 siswa, ada dua siswa yang tidak dapat memenuhi persyaratan indikator kemampuan bertanya. Rintangan yang dialami siswa belum dapat menggunakan bahasa Indonesia dengan benar, kurang fokus dalam bertanya, kurang percaya diri, takut salah, malu ketika ditertawakan oleh teman mereka dan tidak mampu mengangkat suara sehingga pertanyaan dapat menjangkau seluruh kelas. Kesimpulan dari penelitian ini adalah setiap siswa siswa kelas V SD Negeri 60 Kota Bengkulu memiliki kemampuan bertanya yang berbeda.
\end{abstract}

Kata kunci: Kemampuan, Tematik, Tanya Jawab

\section{PENDAHULUAN}

Aktivitas belajar siswa yang tidak lepas dalam kegiatan pembelajaran salah satunya yaitu kegiatan 'menanya' (Questioning). Kegiatan menanya merupakan kegiatan mengajukan pertanyaan dari yang faktual 
hingga bersifat hipotesis yang diawali dengan bimbingan guru sampai dengan mandiri atau menjadi suatu kebiasaan. "Aktivitas menanya siswa dimaksudkan untuk meningkatkan keingintahuan dalam diri siswa dan mengembangkan kemampuan mereka untuk belajar sepanjang hayat”. (Sani, 2014, hal. 57)

Seorang siswa harus memiliki kemampuan untuk mengembangkan pengetahuannya. Kemampuan tersebut salah satunya yaitu kemampuan bertanya. Kemampuan bertanya siswa jarang menjadi perhatian, hal itu terbukti masih belum banyak penelitian yang meneliti tentang kemampuan bertanya yang harus dimiliki siswa, penelitian kemampuan yang banyak diteliti diantaranya yaitu kemampuan bertanya guru, dimana kemampuan itu masuk dalam kategori kemampuan dasar yang harus dimiliki seorang guru. Kemampuan bertanya siswa padahal juga menjadi topik penting yang menarik untuk diteliti dalam pembelajaran yang saat ini diterapkan di Indonesia melalui kurikulum 2013 nya.

Kurikulum 2013 menggunakan pembelajaran tematik dengan pendekatan saintifik sebagai acuan dalam kegiatan belajarnya. Kegiatan "menanya" dalam pendekatan saintifik menjadi tahapan kedua yang harus dilakukan oleh siswa. Bertanya menjadi suatu kesempatan untuk siswa mengembangkan rasa keingintahuan akan sesuatu hal agar dapat memperoleh informasi yang ingin diperolehnya.Berdasarkan observasi awal di SD Negeri 60 Kota Bengkulu, peneliti menemukan di kelas V ada 7 dari 23 siswa yang aktif bertanya namun pertanyaan mereka aneh-aneh sehingga membuat suasana kelas sering menjadi gaduh. Siswa yang telihat pasif atau jarang sekali bertanya kepada guru maupun peneliti saat peneliti praktek mengajar di kelas tersebut ada 2 siswa dari 23 siswa.

Hal itu didukung juga oleh hasil penelitian yang telah dilakukan oleh Dwi ana Lestari (2015) yang menunjukkan bahwa siswa terlihat secara aktif, bersemangat, dan gembira dalam belajar dan kemampuan bertanya siswa dalam pembelajaran mengalami peningkatan dari $70 \%$ menjadi $77 \%$. Siswa menurutnya yang pada awalnya pasif, mulai berani mengajukan pertanyaan dan mengeluarkan pendapatnya dalam diskusi kelompok maupun diskusi kelas. Berdasarkan hasil penelitiannya itu, ia menyimpulkan bahwa penerapan pendekatan ilmiah (saintifik) dapat meningkatkan kemampuan bertanya siswa yang akan berpengaruh terhadap peningkatan hasil belajar siswa.

Rumusan masalah dalam penelitian ini yaitu bagaimana kemampuan bertanya siswa kelas $\mathrm{V}$ mata pelajaran tematik Tema Lingkungan Sahabat Kita Subtema Usaha Pelestarian Lingkungan dan apa saja hambatan yang dialami siswa dalam kemampuan bertanya pada mata pelajaran tematik Tema Lingkungan Sahabat Kita Subtema Usaha Pelestarian Lingkungan kelas V SD Negeri 60 Kota Bengkulu.

Tujuan dari penelitian ini adalah untuk mendeskripsikan kemampuan bertanya siswa dan hambatan yang dialami siswa dalam kemampuan bertanya siswa kelas V pada matapelajaran tematik Tema Lingkungan Sahabat Kita Subtema Usaha Pelestarian Lingkungan SD Negeri 60 Kota Bengkulu tahun pelajran 2019/2020. 
Manfaat dari penelitian ini secara teoritis yaitu diharapkan dapat menambah pengetahuan tentang kemampuan bertanya siswa. Manfaat praktis bagi peneliti adalah diharapkan dapat menggali dan menambah wawasan serta penegetahuan mengenai kemampuan bertanya siswa. Bagi siswa diharapkan dapat memberi masukan bagi siswa bahwa kemampuan bertanya harus dimiliki siswa untuk dapat mengembangkan rasa ingin tahu dan juga pengetahuan yang akan didapatkan dari kegiatan bertanya tersebut. Bagi guru penelitian ini diharapkan mampu memberikan masukan bagi guru agar dapat memacu siswa untuk lebih percaya diri dan lebih aktif untuk bertanya agar tujuan pembelajaran dapat diperoleh secara optimal. Bagi sekolah, penelitian ini diharapkan dapat menjadi bahan pengembangan bagi pihak sekolah untuk lebih memperhatikan metode mengajar guna meningkatkan kemampuan bertanya siswa agar aktif dalam kegiatan pembelajaran. Bagi peneliti selanjutnya, diharapkan penelitian ini dapat menjadi acuan untuk melakukan penelitian pengembangan selanjutnya.

Belajar sebenarnya tidak lepas dari yang namanya bertanya. Belajar adalah bertanya, karena belajar adalah mencari sesuatu yang belum diketahui. Terdapat pepatah yang mengatakan bahwa "Lebih bertanya dari pada sesat dijalan" sehingga bertanya memiliki peranan penting dalam kehidupan seharihari. Bertanya dalam Kamus Besar Bahasa Indonesia adalah meminta keterangan atau penjelasan supaya diberi tahu. Bertanya menurut Brown seperti dikutip Saud (2009, hal. 61) adalah setiap pertanyaan yang mengkaji atau menciptakan ilmu pada diri siswa.Siswa yang aktif bertanya diharapkan memiliki kompetensi untuk mengembangkan kreativitas, rasa ingin tahu mereka dan kemampuan dalam merumuskan pertanyaan yang membentuk pemikiran mereka menjadi lebih kritis terhadap suatu topik maupun permasalahan.

Siswa dapat bertanya tidak hanya dengan guru maupun temannya, siswa dapat bertanya dengan orang lain untuk mendapatkan informasi yang sesuai dengan apa yang diharapkannya. "Bertanya pada semua aktivitas belajar dilakukan antara siswa dengan siswa, antara guru dengan siswa, dan antara siswa dengan guru, antara siswa dengan orang lain yang didatangkan ke kelas.” (Sagala, 2013, hal. 89). Siswa misalnya mengadakan wawancara dengan kepala desa atau ketua RT di daerah tempat tinggalnya tentang kegiatan kebersihan di lingkungannya. Siswa akan berlatih untuk bertanya dengan baik yang dibimbing oleh gurunya sehingga siswa mampu mendapatkan informasi tentang kegiatan yang ada didaerah tempat tinggalnya untuk menjaga kebersihan lingkungan.

Bertanya merupakan strategi utama yang berbasis kontekstual. Bagi guru bertanya dalam proses pembelajaran adalah kegiatan mendorong, membimbing, dan menilai kemampuan berfikir siswa. Bagi siswa, bertanya adalah kegiatan untuk menggali informasi, mengkonfirmasi apa yang sudah di ketahui dan mengarahkan perhatian pada aspek yang dipahami atau belum diketahui (Trianto, 2013, hal.115).

Bertanya memiliki banyak fungsi dalam pembelajaran. Hosnan (2016, hal.50) menyebutkan sebagai berikut.Fungsi bertanya dalam kegiatan pembelajaran diantaranya yaitu: (1) Membangkitkan rasa 
ingin tahu, minat, dan perhatian siswa tentang tema atau topik pembelajaran.(2) Mendorong dan menginspirasi siswa untuk aktif belajar, serta mengembangkan pertanyaan dai dan untuk dirinya sendiri. (3) Mendiagnosis kesulitan belajar siswa sekaligus menyampaikan rancangan untuk mencapai solusi. (4) Menstrukturkan tugas-tugas dan memberikan kesempatan pada siswa untuk menunjukkan sikap, kemampuan, dan pemahaman atas subtansi pembelajaran yang diberikan. (5) Membangkitkan kemampuan siswa dalam berdiskusi, berargumen, mengembangkan kemampuan berpikir, dan menarik kesimpulan. (6) Membangun sikap keterbukaan untuk saling memberi dan menerima pendapat atau gagasan, memperkaya kosa kata, serta mengembangkan toleransi sosial dalam dalam hidup berkelompok. (7) Membiasakan siswa berpikir spontan dan cepat, serta sigap dalam merespon persoalan yang tiba-tiba muncul. (8) Melatih kesantunan dalam berbicara dan membangkitkan kemampuan berempati satu sama lain.

Bertanya selain memiliki fungsi juga memiliki manfaat. Manfaat kegiatan bertanya menurut Sagala (2013, hal. 88) adalah:(1)menggali infomasi; (2) mengecek pemahaman siswa; (3) membangkitkan respon siswa; (4) mengetahui sejauh mana keingintahuan siswa; (5) mengetahui hal-hal yang sudah diketahui siswa; (6) memfokuskan perhatian siswa pada sesuatu yang dikehendaki guru; (7) untuk membangkitkan lebih banyak lagi pertanyaan dari siswa; (8) untuk menyegarkan kembali pengetahuan siswa.

Penelitian ini menggunakan indikator untuk kemampuan bertanya yang diadaptasi dari Hosnan (2016, hal. 51) tentang kriteria pertanyaan yang baik sebagai berikut:

a. Singkat dan Jelas

Pertanyaan yang diajukan hendaknya bersifat ringkas dan mudah dipahami. Pertanyaan yang berbelit-belit akan membuat orang lain kebingungan sebaliknya jika pertanyaan tersebut ringkas maka akan membuat orang lain dengan mudah memahami maksud dari pertanyaan tersebut. Kejelasan suara juga diperlukan untuk bertanya, hal itu dikarenakan agar pertanyaan dapat tersampaikan dengan baik pada telinga pendengarnya. Pertanyaan yang baik juga perlu menggunakan bahasa Indonesia yang baik dan benar, hal itu untuk melatih siswa berbahasa yang baik agar mudah dipahami.

b. Memiliki fokus

Pertanyaan yang baik harus sesuai dengan topik bahasan dan sesuai dengan yang ingin ditanyakan serta tujuannya. Jika pertanyaan yang diungkapkan tidak memiliki fokus maka tidak akan diperoleh informasi atau tidak dapat menjawab topik permasalahan yang sedang diungkap.

c. Bersifat probing atau divergen

Istilah probing memiliki arti berusaha memperoleh keterangan lebih jelas atau lebih mendalam. Sedangkan divergen memiliki arti kata " berbeda". Kaitannya dalam hal ini adalah pertanyaan yang di ajukan harus bervariasi dan memiliki arti yan jelas dan dalam (Nofika, 2019). 
Kemampuan bertanya harus dimiliki siswa yang saat ini menjadi pusat perhatian dalam kurikulum 2013 dengan pendekatansaintifiknya, menuntut siswa harus lebih aktif lagi untuk menggali informasi yang ingin mereka tahu baik itu dengan antar siswa, dengan guru maupun dengan lingkungan sekitarnya. Hosnan (2016, hal. 49) memprediksi bahwa "masih banyak siswa belum secara aktif bertanya dalam proses pembelajaran”. Menurutnya ada beberapa hal yang menyebabkan siswa kurang berani untuk bertanya dikarenakan: "(1) siswa merasa dirinya tidak lebih tau dari guru, sebagai akibat dari kebiasaan belajar satu arah; (2) adanya ganjalan psikologis karena guru lebih dewasa dari pada siswa; (3) kurangnya kreatifitas guru untul mengajukan persoalan-persoalan yang menantang siswa untuk bertanya".

\section{METODE PENELITIAN}

Jenis penelitian yang digunakan oleh peneliti pada penelitian ini adalah jenis deskriptif kualitatif yang mempelajari tentang masalah yang akan diteliti. Penelitian deskriptif kualitatif memasukkan deskripsi terperinci tentang orang dan tempat untuk membawakan naratifnya. (Creswell, 2015 hal. 540). Pendekatan yang digunakan dalam penelitian ini adalah pendekatan deskriptif kualitatif dimana dalam penelitian ini lebih menekankan proses dari pada hasil. Pendekatan kualitatif menurut Creswell (2015) adalah pendekatan penelitian yang berguna untuk mengeksplorasi dan memahami fenomena sentral, untuk mempelajarinya peneliti menanyakan pertanyaan-pertanyaan umum dan luas kepada subjek penelitian, mengumpulkan pandangan terperinci subjek dalam bentuk kata-kata atau gambar dimana struktur final laporan penelitian bersifat fleksibel dan memperlihatkan pikiran peneliti.

\section{Subjek dan Objek Penelitian}

Partisipan pada penelitian ini adalah siswa kelas V SD Negeri 60 Kota Bengkulu yang berjumlah 18 siswa yang terdiri dari 9 siswa laki-laki dan 9 siswa perempuan. Pelaksanaan penelitian ini dilaksanakan pada Oktober 2019 di SD Negeri 60 Kota Bengkulu.

\section{Instrumen}

Instrumen pada penelitian ini terdiri dari dua yaitu peneliti sebagai instrumen utama dan dan intrumen pendukung berupa lembar observasi dan lembar wawancara siswa dan guru.

\section{Teknik Pengumpulan Data}

Teknik pengumpulan data mebggunakantiga teknik berupa observasi, wawancara dan dokumentasi.

\section{Teknik Analisis Data}

Analisis data yang dilakukan peneliti menggunakan analisis yang dikemukakan oleh Sugiono (2015) yaitu berupa reduksi data, penyajian data dan verifikasi data (penarikan kesimpulan). Dan untuk 
pengecekan keabsahan data menggunkan tahapan triangulasi dan pemeriksaan dengan dosen dan guru melalui diskusi.

\section{HASIL DAN PEMBAHASAN}

\section{Hasil}

Berikut merupakan uraian dari hasil observasi dan wawancara yang telah dilakukan peneliti dengan siswa pada tanggal 21 Oktober 2019 dan 23 Oktober 2019 di kelas V dengan jumlah siswa yang di teliti sebanyak 18 siswa dari 23 siswa yaitu sebagai berikut:

1) Nama $: \mathrm{AD}$

Jenis Kelamin : Laki-Laki

Deskripsi :

AD merupakan siswa yang aktif dikelas. AD mampu bertanya dengan singkat dan jelas tanpa berbelit-belit. Saat bertanya suara AD mampu menjangkau isi ruang kelas. Meski pertanyaan yang ia ajukan singkat dan jelas akan tetapi pertanyaannya tidak memiliki fokus. Dia bertanya untuk memancing keriuhan di kelas. Bentuk pertanyaan AD yaitu "Lha lek ninglaut akeh sampab mosok yo arep di saponi?”. Berdasarkan pertanyaan AD tersebut terlihat jika pertanyaan itu tidak bersifat menggali informasi lebih dalam meskipun pertanyaannya bervariasi. Bahasa yang ia gunakan untuk bertanya yaitu bahasa Jawa. Berdasarkan hasil wawancara ia mengungkapkan jika ia lebih sering menggunakan bahasa Jawa dibandingkan dengan Bahasa Indonesia. Respon guru saat siswa bertanya menggunakan bahasa Jawa tidak masalah.

2) Nama : NL

Jenis Kelamin : Perempuan

Deskripsi

NL merupakan siswa yang pendiam. Dia tidak terlihat aktif seperti teman-teman yang lainnya. Saat teman-temannya riuh riang tertawa ia hanya terlihat ikut tersenyum saja. NL tidak melontarkan pertanyaan saat peneliti melakukan observasi selama pembelajaran tema lingkungan sahabat kita subtema usaha pelestarian lingkungan. Terlihat ia tampak malu-malu saat berbicara dengan temantemannya. Ternyata hal itu juga selaras dengan hasilwawancara yang peneliti lakukan dengan NL, peneliti ingin lebih banyak menggali informasi kenapa ia tidak bertanya saat pembelajaran berlangsung. Berikut merupakan hasil wawancara peneliti dengan NL tentang tanggapan temantemannya saat ia bertanya namun suaranya tidak dapat menjangkau isi ruang kelas. "Diteriaki agar saya mengulangi lagi bu.” Berdasarkan jawaban tersebut peneliti juga menggali informasi tentang bagaimana biasanya tanggapan guru saat seperti itu. Berikut jawaban NL: “ Kadang di dekati dan diminta untuk mengulangi itu". Berdasarkan hal itu dapat di ketahui bahwa guru juga menaruh 
perhatian dan juga memberikan pengarahan kepada siswa agar kemampuan bertanya dapat terlaksana dengan baik sesuai yang harapkan. Selain itu, informasi lain yang didapatkan peneliti dari hasil wawancara dengan NL bahwa NL merasa malu saat ditunjuk guru untuk bertanya, ia malu jika pertanyaan yang ia lobntarkan salah dan di tertawakan oleh temna-temannya. NL juga pernah merasa kebingungan karena pertanyaan yang ingin disampaikan oleh NL sudah ditanyakan oleh temntemanya. Untuk hasil observasi dan wawancara secara lengkap dengan NL dapat dilihat pada lampiran.

3) Nama $: \mathbf{N N}$

Jenis Kelamin : Perempuan

Deskripsi

NN merupakan siswa yang pemalu. Ia di hampiri guru untuk mengulangi pertanyaan yang ia ajukan. Bentuk pertanyaan NN yaitu sebagi berikut "Bagaimana cara mengolah limbah agar tidak mencemari lingkungan?”. Berdasarkan pertanyaan tersebut dapat diketahui jika bentuk pertanyaan NN meupakan pertanyaan yang singkat dan jelas, memiliki fokus, bervariasi dan bersifat mendalam. Namun kendalanya, ia memiliki suara yang lembut sehingga saat bertanya pertanyaan tersebut harus diulanginya hingga beberapa kali agar teman-teman maupun guru dapat mendengar pertanyaan tersebut. Hal itu ternyata didukung berdasarkan hasil wawancara peneliti dengan NN tentang perasannya saat diminta untuk mengulangi pertanyaan. "Saya gugup bu. saya malu dan takut salah. Biasanya saya di tertawakan oleh teman-teman". Berdasarkan hasil wawancara tersebut ternyata NN tidak bisa memaksimalkan suaranya karena memang suara yang dimilikinya lembut dan ia merupakan siwa yang pemalu. Untuk hasil observasi dan wawancara secara lengkap dengan NN dapat dilihat pada lampiran.

4) Nama

\section{: AM}

Jenis Kelamin : Perempuan

Deskripsi

AM merupakan siswa yang pendiam. Ia tidak bertanya pada saat kegiatan pembelajaran berlangsung. Berdasarkan hasil wawancara peneliti dengan AM tentang apa yang membuat AM tidak bertanya yaitu ia takut dan malu untuk bertanya

Simpulan dari hasil observasi seperti di atas pada penelitian ini dapat diketahui bahwa semua siswa memiliki kemampuan akan kemampuan bertanya yang berbeda beda. Siswa yang mampu memenuhi semua indikator kemampuan bertanya sebanyak 7 siswa diantaranya yaitu AN, IL, LA, STR, TT, DV, dan PT. Untuk siswa yang dapat memenuhi satu indikator kemampuan bertanya sebanya 3 siswa yaitu FK, RF, dan BST. Untuk Siswa yang mampu memenuhi dua indikator kemampuan bertanya sebanyak 6 siswa, 
diantaranya yaitu AD, EK, RO, AK, dan NN. Sedangkan untuk siswa yang sama sekali belum mampu memenuhi indikator kemampuan bertanya ada 2 siswa yaitu AM dan NL.

Hambatan yang dihadapi siswa dalam kemampuan bertanya berdasarkan hasil observasi siswa yang mampu menggunakan bahasa Indonesia dengan baik dan benar sebanyak 4 anak. Yaitu AN, IL, STR dan TT, sedangkan untuk 14 siswa lain menggunakan bahasa campuran yaitu bahasa Jawa dan bahasa Indonesia.

Siswa saat bertanya tentu membutuhkan energi suara yang cukup untuk menjangkau seluruh ruangan kelas agar pertanyaan dapat tersampaikan dengan baik. Siswa yang memiliki suara yang lembut sebanyak 3 siswa, sehingga saat melontarkan pertanyaan ia diminta untuk mengulangi pertanyaan tersebut. Sesuai dengan hasil observasi yang peneliti lakukan ketiga siswa yang memiliki suara yang lembut yaitu AM, NL, dan NN.

Saat siswa diberikan kesempatan untuk bertanya oleh guru namun tidak ada siswa yang bertanya maka guru menunjuk langsung siswa secara acak. Perasaan merekapun juga beraneka ragam, ada yang merasa gugup, malu, dan juga senang saat di tunjuk untuk bertanya.

Siswa terkadang bertanya tidak sesuai topik pelajaran sehingga menjadi bahan bercandaan yang membuat suasana menjadi ramai di dalam kelas. Bapak Suyanto, S.Pd. beberapa kali memberikan teguran kepada siswa agar suasana kelas dapat menjadi kondusif kembali saat ada teman yang melontarkan pertanyan yang tidak sesuai dengan topik pelajaran.

\section{Pembahasan}

Kemampuan bertanya yang baik dilihat dari indikator kemampuan bertanya menurut Hosnan (2016) yaitu pertanyaan yang baik itu meliputi tiga hal sebagai beriku: a) singkat dan jelas, b) memiliki fokus), dan c)bersifat probing dan divergen. Dari ketiga indikator tersebut yang telah di kembangkan peneliti kedalam berbagai pernyataan menunjukkan bahwa semua siswa memiliki kemampuan akan kemampuan bertanya yang berbeda beda. Siswa yang mampu memenuhi semua indikator kemampuan bertanya sebanyak 7 siswa diantaranya yaitu AN, IL, LA, STR, T'T, DV, dan PT. Untuk siswa yang dapat memenuhi satu indikator kemampuan bertanya yaitu FK, RF, dan BST. Untuk Siswa yang mampu memenuhi dua indikator kemampuan bertanya sebanyak 6 siswa, diantaranya yaitu AD, EK, RO, AK, dan NN. Sedangkan untuk siswa yang sama sekali belum mampu memenuhi indikator kemampuan bertanya ada 2 siswa yaitu AM dan NL.

Berdasarkan hasil observasi, wawancara dengan siswa dan wawancara dengan guru yang telah diuraikan dapat diketahui jika sebagian besar siswa telah mampu bertanya dengan bahasa yang singkat dan jelas namun bahasa yang siswa gunakan masih belum sesuai. Siswa menggunakan bahasa sehari-hari (Bahasa Jawa) yang di campur dengan Bahasa Indonesia. Untuk indikator kemampuan bertanya yaitu saat saat bertanya harus memiliki fokus, siswa belum cukup mampu karena mereka terkadang masih bertanya 
keluar dari topik pembahasan yang di selingi dengan bercanda. Sedangkan untuk indikator bersifat probing dan divergen siswa telah mampu untuk memvariasikan pertanyaan sesuai dengan kebutuhan pengetahuan yang ingin mereka dapatkan dengan menggunakan kata tanya apa, siapa, dimana, mengapa, kapan dan bagaimana.

Kemudian, 2 siswa tidak bertanya pada kegitan pembelajaran. Dia mengalami hambatan dalam kemampuan bertanya yaitu ia merasa bingung mau bertanya apa dan malu untuk bertanya. Dua siswa tersebut adalah AM dan NL. Dari hal tersebut tebukti jika di kaitkan dengan hasil teori Hosnan (2016, hal. 49) yang memprediksi bahwa "masih banyak siswa belum secara aktif bertanya dalam proses pembelajaran". Menurutnya ada beberapa hal yang menyebabkan siswa kurang berani untuk bertanya dikarenakan: (1) siswa merasa dirinya tidak lebih tau dari guru, sebagai akibat dari kebiasaan belajar satu arah; (2) adanya ganjalan psikologis karena guru lebih dewasa dari pada siswa; (3) kurangnya kreatifitas guru untul mengajukan persoalan-persoalan yang menantang siswa untuk bertanya.

\section{SIMPULAN}

Berdasarkan hasil penelitian yang telah dilakukan pada siswa kelas V SD Negeri 60 Kota Bengkulu, dapat diambil kesimpulan bahwa:

1. Semua siswa memiliki kemampuan akan kemampuan bertanya yang berbeda beda. Siswa yang mampu memenuhi semua indikator kemampuan bertanya sebanyak 7 siswa. Siswa yang mampu memenuhi satu indikator kemampuan bertanya sebanyak 1 siswa. Untuk Siswa yang mampu memenuhi dua indikator kemampuan bertanya sebanyak 6 siswa. Sedangkan untuk siswa yang sama sekali belum mampu memenuhi indikator kemampuan bertanya ada 2 siswa.

2. Hambatan yang dialami siswa dalam kemampuan bertanya meliputi siswa belum mampu dalam menggunakan bahasa Indonesia secara baik dan benar, siswa kurang dapat memiliki fokus dalam bertanya, rasa malu saat akan bertanya, takut salah, malu jika tertawakan teman, dan kurang dapat memaksimalkan suara yang di miliki sehingga suara tidak dapat menjangkau seluruh isi kelas.

\section{DAFTAR PUSTAKA}

Creswell, J. (2015). Riset Pendidikan; Perencanaan, Pelaksanaan, dan EvaluasiRiset Kualitatif dan Kuantitatif. Yogyakarta: Pustaka Pelajar

Hosnan. (2016). Pendekatan Saintifik dan Kontekstual dalam Pembelajaran Abad 21(ed. 2). Jakarta: Ghalia Indonesia

Lestari, D. A. (2015). Pendekatan Saintifik dalam Pembelajaran Tematik untuk Meningkatkan Kemampuan Bertanya Siswa. Widyagogik 3(1), 66-78

Nofika, M. (2019). Pengembangan Kemampuan Bertanya Siswa dalam Pembelajaran tentang Vektor Menggunakan Model Pembelajaran Problem Composing. In Skripsi. Yogyakarta: Prodi Fisika Universitas Sanata Dharma.

Sagala, S. (2013). Konsep dan Makna Pembelajaran: Untuk Membantu Memecahkan Problematika Belajar Mengajar. Bandung: Alfabeta. 
Sani, R. A. (2014). Pembelajaran Saintifik untuk Implementasi Kurikulum 2013. Jakarta: Bumi Aksara. Saud, U. S. (Ed.). (2009). Pengembangan Profesi Guru. Bandung: Alfabeta.

Sugiono. (2015). Metode Penelitian Pendidikan; Pendekatan Kuantitatif, Kualitatifdan R\&D. Bandung: Alfabeta Trianto. (2013). Mendesain Model Pembelajaran Inovatif-Progresif: Konsep, Landasan dan Implementasi pada Kurikulum Tingkat Satuan Pendidika (KTSP) (ed. 6). Jakarta: Kencana Prenadamedia Group 